\title{
Dehydroepiandrosterone inhibits cell proliferation and improves viability by regulating $S$ phase and mitochondrial permeability in primary rat Leydig cells
}

\author{
LIN LIU, DIAN WANG, LONGLONG LI, XIAO DING and HAITIAN MA
}

Key Laboratory of Animal Physiology and Biochemistry, College of Veterinary Medicine, Nanjing Agricultural University, Nanjing, Jiangsu 210095, P.R. China

Received July 8, 2015; Accepted May 9, 2016

DOI: $10.3892 / \mathrm{mmr} .2016 .5343$

\begin{abstract}
Dehydroepiandrosterone (DHEA) is widely used as a nutritional supplement and exhibits putative anti-aging properties. However, the molecular basis of the actions of DHEA, particularly on the biological characteristics of target cells, remain unclear. The aim of the current study was to investigate the effects of DHEA on cell viability, cell proliferation, cell cycle and mitochondrial function in primary rat Leydig cells. Adult Leydig cells were purified by Percoll gradient centrifugation, and cell proliferation was detected using a Click-iT ${ }^{\circledast}$ EdU Assay kit and cell cycle assessment performed using flow cytometry. Mitochondrial membrane potential was detected using JC-1 staining assay. The results of the current study demonstrate that DHEA decreased cell proliferation in a dose-dependent manner, whereas it improved cell viability in a time-dependent and dose-dependent manner. Flow cytometry analysis demonstrated that DHEA treatment increased the $\mathrm{S}$ phase cell population and decreased the G2/M cell population. Cyclin A and CDK2 mRNA levels were decreased in primary rat Leydig cells following DHEA treatment. DHEA treatment decreased the transmembrane electrical gradient in primary Leydig cells, whereas treatment significantly increased succinate dehydrogenase activity. These results indicated that DHEA inhibits primary rat Leydig cell proliferation by decreasing cyclin mRNA level, whereas it improves cells viability by modulating the permeability of the mitochondrial membrane and succinate dehydrogenase activity. These findings may demonstrate an important molecular mechanism by which DHEA activity is mediated.
\end{abstract}

Correspondence to: Dr Haitian Ma, Key Laboratory of Animal Physiology and Biochemistry, College of Veterinary Medicine, Nanjing Agricultural University, 1 Weigang, Nanjing, Jiangsu 210095, P.R. China

E-mail:mahaitian@njau.edu.cn

Key words: DHEA, cell proliferation, cell viability, mitochondrial function, leydig cell

\section{Introduction}

Dehydroepiandrosterone (DHEA), an intermediate produced during the biosynthesis of steroids hormones, is secreted by the adrenal cortex in an age-dependent manner (1). Previous studies have demonstrated that DHEA exerts numerous beneficial effects, including prevention of obesity (2), cancer (3), atherosclerosis (1) and age-induced changes to the brain (4). The decrease in DHEA levels with age is of significant clinical interest as DHEA reduction is associated with physical health. In the United States, DHEA is widely used as a non-prescribed dietary supplement (5).

The exact mechanisms of DHEA action remain unknown, however, it may function through conversion to active steroid hormones or effect certain metabolic enzymes, such as glucose-6-phosphate dehydrogenase (G6PD) (6). DHEA is a pro-hormone and is rapidly converted into testosterone and estradiol within peripheral target tissues (7). A previous investigation demonstrated that serum testosterone and estradiol content were markedly increased in male rats following treatment with DHEA (8). Additionally, previous observations suggested that restoration of DHEA may alter hormone contents resulting in anti-aging effects (9). However, the action of DHEA on the biological characteristics of Leydig cells, which is major cell type involved in DHEA biotransformation, remains unclear.

Previous studies have demonstrated that DHEA exerts anti-proliferative effects in animal tumor models and in malignant cell lines (10-12) through its inhibitory effects on G6PD activity, which is essential for cell growth $(6,11)$. A previous study demonstrated that DHEA inhibits 3T3-L1 cell proliferation, which was associated with G1 phase cell cycle arrest (13). Zapata et al (14) demonstrated that DHEA inhibits mesodermal cell proliferation. In addition to metabolic regulation, mitochondria are also critical for modulating other cellular functions. Correa et al (15) demonstrated that DHEA inhibits malate-glutamate oxidation by blocking Site I electron transport in the respiratory chain, and induces mitochondrial swelling and transmembrane electrical gradient collapse in isolated rat kidney mitochondria. However, the mechanism of the effects of DHEA on mitochondrial function is not fully understood. 
It has been previously reported that the biosynthesis and secretion of most androgen occurs in Leydig cells. A previous study in Leydig cells suggested that functional changes to the cells, rather than loss, cause the serum testosterone level reduction (8). However, the molecular mechanisms underlying the DHEA mode of action in primary rat Leydig cells remain to be identified. The, the present study aimed to investigate the effect of DHEA on cell proliferation and mitochondrial function in primary rat Leydig cells. This investigation is important to fully elucidate the cellular mechanisms of DHEA activity and its effects in vivo.

\section{Materials and methods}

Animal and materials. Male Sprague-Dawley rats weighing $200 \pm 20 \mathrm{~g}$ were purchased from Shanghai Experimental Animal Center of the Chinese Academy of Sciences (Shanghai, China). DHEA, dimethyl sulfoxide (DMSO), penicillin, streptomycin, trypsin and Percoll were purchased from Sigma-Aldrich (St. Louis, MO, USA). Transferrin, L-glutamine and 4-(2-hydroxyethyl)-1-piperazineethanesulfonic acid (HEPES) were obtained from Amresco, LLC (Solon, OH, USA). Methyl thiazolyl tetrazolium (MTT) was obtained from Sunshine Biotech International Co., Ltd. (Bengbu, China). Dulbecco's modified Eagle's medium (DMEM)-F12 and fetal bovine serum (FBS) were purchased from Hyclone (GE Healthcare Life Sciences, Logan, UT, USA). Click-iT EdU Imaging kits were purchased from Thermo Fisher Scientific, Inc. (Waltham, MA, USA). TRIzol reagent was purchased from Invitrogen (Thermo Fisher Scientific, Inc.). M-MLV reverse transcriptase, RNase inhibitor and dNTP mixture were obtained from Promega Corporation (Madison, WI, USA), and SYBR Green PCR Master Mix was purchased from Takara Biotechnology Co., Ltd. (Dalian, China). Propidium iodide cell cycle assay kit was obtained from Multi Sciences (Lianke) Biotech Co., Ltd. (Hangzhou, China), and 5,5', 6,6'-tetrachloro-1,1', 3,3'-tetraethyl benzimidazol carbocyanineiodide (JC-1) lipophiliccation kit, mitochondrial membrane potential $(\Delta \Psi \mathrm{m})$ detection kits and bicinchoninic acid protein assay kits were obtained from the Beyotime Institute of Biotechnology (Haimen, China).

Primary Leydig cell culture. Male rats (2 months old) were housed individually under a constant temperature of $25^{\circ} \mathrm{C}$ and $56-60 \%$ humidity, with a 12 h light-dark cycle. All animal handling procedures were performed in strict accordance with guide for the Care and Use of Laboratory Animals Central of the Nanjing Agricultural University (Nanjing, China). The protocol was approved by the Institutional Animal Care and Use Committee of the Nanjing Agricultural University (Nanjing, China). Rats were killed by decapitation and Leydig cells were isolated by enzymatic digestion and purified using discontinuous Percoll gradient according to the method previously described by Murugesan et al (16). The purity of Leydig cells was assessed by $3 \beta$-hydroxysteroid dehydrogenase histochemical localization according to the method previously described by Aldred and Cooke (17), and using trypan blue dye exclusion to determine the viability of purified Leydig cells. Subsequently, cells were cultured in DMEM-F12 supplemented with $10 \% \mathrm{FBS}, 5 \mathrm{mg} / \mathrm{ml}$ transferrin, $2 \mathrm{mM}$
L-glutamine, $1.75 \mathrm{mM}$ HEPES, $100 \mathrm{IU} / \mathrm{ml}$ penicillin and $100 \mathrm{mg} / \mathrm{ml}$ streptomycin in an atmosphere of $95 \%$ air and $5 \%$ $\mathrm{CO}_{2}$ at $37^{\circ} \mathrm{C}$.

Cell viability assay. Primary Leydig cells were seeded in 96-well plates at a density of $1 \times 10^{4}$ cells/well and treated with $0.1,1,10,50,100$ or $200 \mu \mathrm{M}$ DHEA for $6,12,24$ or $48 \mathrm{~h}$ before MTT assay. In brief, $20 \mu \mathrm{l}$ MTT $(5 \mathrm{mg} / \mathrm{ml})$ was added to each well, and the plate was incubated for $4 \mathrm{~h}$. Culture medium was removed and the blue formazan crystals were dissolved in $50 \mu 1 \mathrm{DMSO}$, then the optical density $\left(\mathrm{OD}_{490 \mathrm{~nm}}\right)$ was measured using a model 550 microplate reader (Bio-Rad Laboratories, Inc., Hercules, CA, USA).

Morphological observation of cell growth. Primary rat Leydig cells were plated in 6-well plates at a density of $1 \times 10^{6}$ cells/well and incubated for $24 \mathrm{~h}$ before treatment. The medium in each well was then supplemented $0,1,50$ or $100 \mu \mathrm{M}$ DHEA. The cells were imaged using a phase contrast microscope after $24 \mathrm{~h}$.

EdU-based cell proliferation assays. Cell proliferation assays were performed using a Click-iT EdU assay kit according to the manufacturer's instructions. Briefly, the cells were plated at a density of $1 \times 10^{6}$ cells/well for $24 \mathrm{~h}$. Fresh medium supplemented with $0,1,50$ or $100 \mu \mathrm{M}$ DHEA was added in each well, the cells were cultured for $24 \mathrm{~h}$, then $100 \mu \mathrm{l}$ 5'-ethynyl-2'-deoxyuridine (EdU) solution was added at a $50 \mu \mathrm{M}$ final concentration for $2 \mathrm{~h}$. Cells were harvested and collected into $3 \mathrm{ml}$ PBS containing $1 \%$ bovine serum albumin (GE Healthcare Life Sciences), centrifuged at 1,500 x g for $10 \mathrm{~min}$ at $4^{\circ} \mathrm{C}$ and fixed with $100 \mu \mathrm{l} 4 \%$ formaldehyde for $15 \mathrm{~min}$. Following formaldehyde fixation, cells were washed and then incubated with $100 \mu 1$ saponin-based permeabilization buffer for $15 \mathrm{~min}$. Cells were then incubated with $500 \mu \mathrm{l}$ Click-iT reaction buffer for $1 \mathrm{~h}$ and washed with $3 \mathrm{ml}$ permeabilization buffer. EdU-stained cells were mounted and imaged by fluorescence microscopy.

Flow cytometry analysis of the cell cycle. Primary rat Leydig cells were plated in 6-well plates $\left(1 \times 10^{6}\right.$ cells/well) and treated with $0,1,50$ or $100 \mu \mathrm{M}$ DHEA for $6 \mathrm{~h}, 12 \mathrm{~h}, 24 \mathrm{~h}$ or $48 \mathrm{~h}$. Cells were then trypsinized, harvested and fixed in $1 \mathrm{ml}$ $80 \%$ cold ethanol and incubated at $4^{\circ} \mathrm{C}$ for $15 \mathrm{~min}$. The cells were then centrifuged at $1500 \mathrm{x}$ g for $5 \mathrm{~min}$. The cell pellets were re-suspended in $500 \mu \mathrm{l}$ propidium iodine $(50 \mu \mathrm{g} / \mathrm{ml})$ containing $5 \mathrm{U}$ RNase and incubated on ice for $15 \mathrm{~min}$. Cell cycle distribution was calculated from 10,000 cells with ModFit LT software (Verity Software House, Inc., Topsham, ME, USA) using a FACSCaliber flow cytometer (BD Biosciences, Franklin Lakes, NJ, USA).

Reverse transcription-quantitative polymerase chain reaction $(R T-q P C R)$. Primary rat Leydig cells were cultured in 6-well plates $\left(1 \times 10^{6}\right.$ cells/well) and treated with 1,50 or $100 \mu \mathrm{M}$ DHEA for $24 \mathrm{~h}$. The cells were then harvested and total RNA was extracted using TRIzol reagent according to the manufacturer's instructions. RT was performed on $2 \mu \mathrm{g}$ total RNA by incubation for $1 \mathrm{~h}$ at $37^{\circ} \mathrm{C}$ in a $25 \mu \mathrm{l}$ mixture consisting of $100 \mathrm{U}$ M-MLV reverse transcriptase, $8 \mathrm{U}$ RNase inhibitor, 
Table I. Primer sequence of $\beta$-actin and targeted genes.

\begin{tabular}{|c|c|c|c|c|}
\hline Gene & $\begin{array}{c}\text { Genbank acession } \\
\text { number }\end{array}$ & Primer sequence $\left(5^{\prime}-3^{\prime}\right)$ & Orientation & Product size (bp) \\
\hline$\beta$-actin & NM_031144 & $\begin{array}{l}\text { CCCTGTGCTGCTCACCGA } \\
\text { ACAGTGTGGGTGACCCCGTC }\end{array}$ & $\begin{array}{l}\text { Forward } \\
\text { Reverse }\end{array}$ & 186 \\
\hline Cyclin A & NM_053702 & $\begin{array}{l}\text { ATGTCAACCCCGAAAAAGTA } \\
\text { GGGACGTGCTCATCATCGTTTAT }\end{array}$ & $\begin{array}{l}\text { Forward } \\
\text { Reverse }\end{array}$ & 154 \\
\hline Cyclin B & NM_171991 & $\begin{array}{l}\text { CTGACCCAAACCGCTGTA } \\
\text { GTCACTTCACGACCCTGT }\end{array}$ & $\begin{array}{l}\text { Forward } \\
\text { Reverse }\end{array}$ & 109 \\
\hline CDK2 & NM_199501 & $\begin{array}{l}\text { CCСТTTCTTCCAGGATGTGA } \\
\text { AGCAGAAGGCTGACCTGTGT }\end{array}$ & $\begin{array}{l}\text { Forward } \\
\text { Reverse }\end{array}$ & 124 \\
\hline
\end{tabular}

CDK2, cyclin-dependent kinase 2.

Table II. Impact of DHEA on primary rat Leydig cell viability (optical density $\left.{ }_{490}\right)$.

\begin{tabular}{|c|c|c|c|c|}
\hline \multirow{2}{*}{$\begin{array}{l}\text { Group } \\
(\mu \mathrm{mol} / \mathrm{l})\end{array}$} & \multicolumn{4}{|c|}{ Incubation time } \\
\hline & $6 \mathrm{~h}$ & $12 \mathrm{~h}$ & $24 \mathrm{~h}$ & $48 \mathrm{~h}$ \\
\hline Control & $0.311 \pm 0.018$ & $0.722 \pm 0.022$ & $0.867 \pm 0.048$ & $1.226 \pm 0.030$ \\
\hline 0.1 & $0.309 \pm 0.037$ & $0.731 \pm 0.034$ & $0.984 \pm 0.01^{\mathrm{b}}$ & $1.289 \pm 0.036^{\mathrm{b}}$ \\
\hline 1.0 & $0.312 \pm 0.019$ & $0.690 \pm 0.023$ & $1.028 \pm 0.040^{\mathrm{b}}$ & $1.395 \pm 0.033^{\mathrm{b}}$ \\
\hline 10.0 & $0.307 \pm 0.019$ & $0.804 \pm 0.050$ & $1.236 \pm 0.039^{\mathrm{b}}$ & $1.799 \pm 0.037^{\mathrm{b}}$ \\
\hline 50.0 & $0.422 \pm 0.037^{\mathrm{b}}$ & $0.870 \pm 0.049^{\mathrm{b}}$ & $1.295 \pm 0.019^{\mathrm{b}}$ & $1.843 \pm 0.067^{\mathrm{b}}$ \\
\hline 100.0 & $0.520 \pm 0.023^{b}$ & $0.990 \pm 0.044^{\mathrm{b}}$ & $1.222 \pm 0.044^{\mathrm{b}}$ & $1.871 \pm 0.102^{b}$ \\
\hline 200.0 & $0.766 \pm 0.033^{b}$ & $1.230 \pm 0.019^{\mathrm{b}}$ & $1.270 \pm 0.042^{\mathrm{b}}$ & $1.760 \pm 0.075^{\mathrm{b}}$ \\
\hline
\end{tabular}

$0.5 \mu \mathrm{g}$ of oligo dT, $50 \mathrm{mM}$ Tris- $\mathrm{HCl}$ (pH 8.3), $3 \mathrm{mM} \mathrm{MgCl}_{2}$, $75 \mathrm{mM} \mathrm{KCl}, 10 \mathrm{mM}$ dithiothreitol and $0.8 \mathrm{mM}$ dNTP.

An aliquot of cDNA sample was mixed with $25 \mu 1 \mathrm{SYBR}$ Green PCR Master Mix (Takara Biotechnology Co., Ltd.) and 10 pmol forward and reverse primers for $\beta$-actin (internal control), cyclin-dependent kinase 2 (CDK2), cyclin A and cyclin B (Table I), and then it was subjected to PCR under standard conditions. All samples were analyzed in duplicate using the ABI Prism 7300 Sequence Detection System (Applied Biosystems; Thermo Fisher Scientific, Inc.) and programmed to conduct one cycle of $95^{\circ} \mathrm{C}$ for $1 \mathrm{~min}$, then 40 cycles of $95^{\circ} \mathrm{C}$ for $30 \mathrm{sec}, 60^{\circ} \mathrm{C}$ for $30 \mathrm{sec}$ and $72^{\circ} \mathrm{C}$ for $40 \mathrm{sec}$. The $2^{-\Delta \Delta \mathrm{Cq}}$ method was used to calculate the fold change in mRNA levels (18). The primer sequences were designed according to the published guidelines (19) or using Primer Premier (version 5; Premier Biosoft International, Palo Alto, CA, USA), and synthesized by Takara Biotechnology Co., Ltd.

Quantification of mitochondria. The method used in the present study was modified from the method described by Tang et al (20). Briefly, primary rat Leydig cells were cultured in 6 -well plates $\left(1 \times 10^{6}\right.$ cells/well $)$ and treated with $1 \mu \mathrm{M}$,
$50 \mu \mathrm{M}$ and $100 \mu \mathrm{M}$ DHEA. After $24 \mathrm{~h}$, cells were fixed in $2.5 \%$ glutaraldehyde in $0.1 \mathrm{M}$ sodium phosphate $(\mathrm{pH} 7.4)$ and centrifuged at $3000 \mathrm{xg}$ for $3 \mathrm{~min}$ at $4^{\circ} \mathrm{C}$. The cells were rinsed in $0.1 \mathrm{M}$ sodium phosphate buffer $(\mathrm{pH} 7.4)$ and post-fixed in $1 \%$ osmium tetroxide in Millonig's buffer. Then, cell samples were processed by standard techniques for transmission electron microscopy (TEM) (21). Ultra-thin sections (60 nm) were stained with uranyl acetate and lead citrate and visualized using an H-7650 transmission electron microscope (Hitachi, Ltd., Tokyo, Japan). The number of mitochondria were counted in 15 independent cells of 30 randomly selected fields.

Mitochondrial membrane permeability assay. A JC-1 $\Delta \Psi \mathrm{m}$ detection kit was used to determine $\Delta \Psi \mathrm{m}$ according to the manufacturer's protocol. Briefly, $2 \times 10^{6}$ cells were collected and re-suspended in $0.5 \mathrm{ml}$ medium. The cells were mixed thoroughly with $0.5 \mathrm{ml} \mathrm{JC}-1$ dye and incubated at $37^{\circ} \mathrm{C}$ for $20 \mathrm{~min}$ in the dark prior to analysis using a flow cytometer (BD Bioscience). The JC-1 monomer and polymer have an excitation wavelength at 490 and $525 \mathrm{~nm}$, and emission wavelength at 530 and $590 \mathrm{~nm}$. Under low $\Delta \Psi \mathrm{m}$ conditions, JC-1 


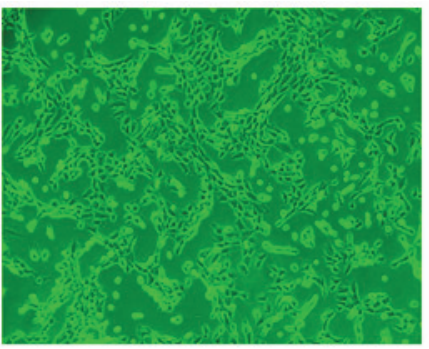

Control (x100)

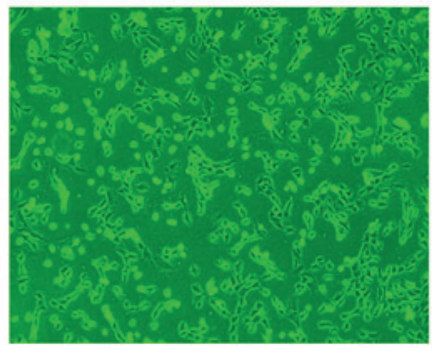

$1 \mu \mathrm{M}$ DHEA (x100)

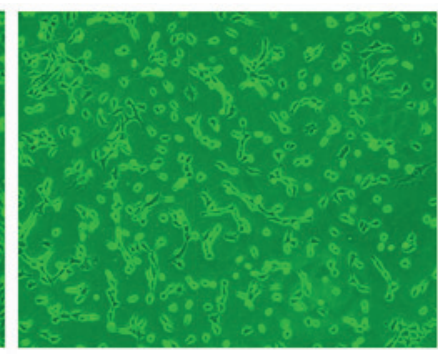

$50 \mu \mathrm{M}$ DHEA (x100)

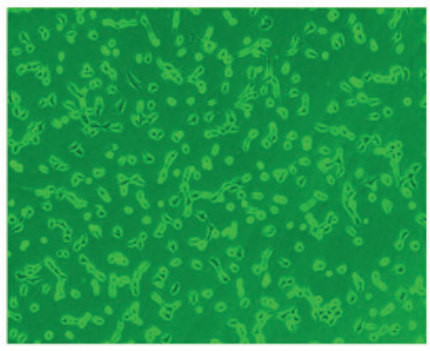

$100 \mu \mathrm{M}$ DHEA (x100)

Figure 1. Effect of DHEA on primary rat Leydig cells growth. Cell growth was observed and photographed using a phase contrast microscope; magnification, x100. After $24 \mathrm{~h}$ incubation, primary rat Leydig cells growth was inhibited by DHEA in a dose-dependent manner. DHEA, dehydroepiandrosterone.

A

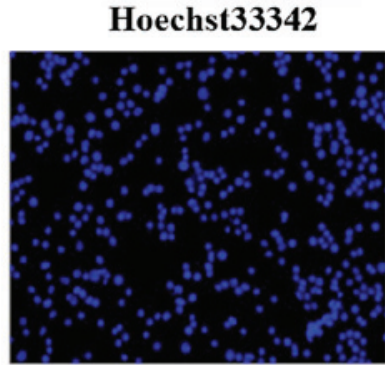

B

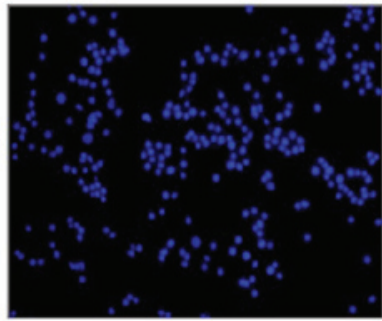

C

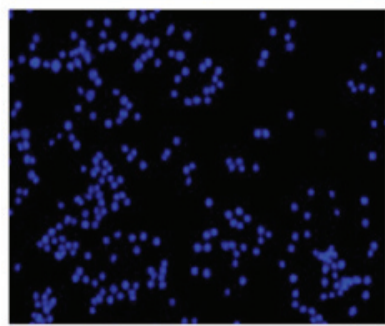

D

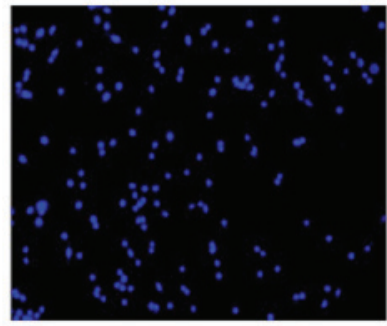

Edu
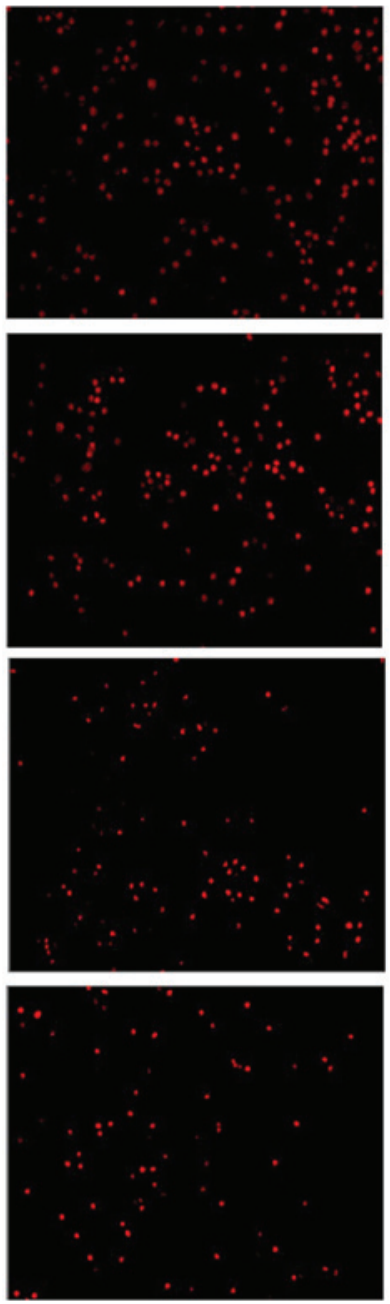

Merged
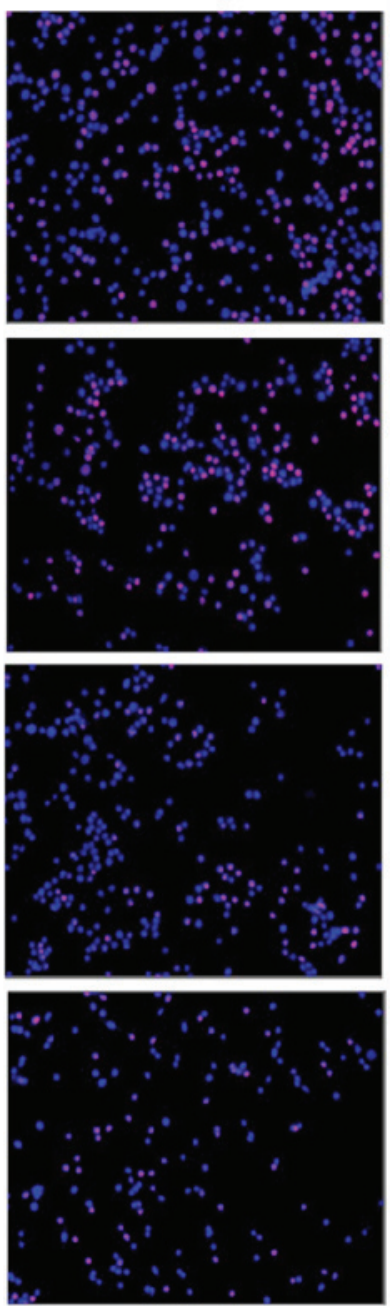

Figure 2. EdU (5'-ethynyl-2'-deoxyuridine) labels cells proliferating in primary rat Leydig cells. (A) Control group cells and cells treated with (B) $1 \mu \mathrm{M}$, (C) $50 \mu \mathrm{M}$ and (D) $100 \mu \mathrm{M}$ DHEA were stained with DNA marker (Hoechst33342) and EdU. The merged images in the right hand column and the pink color in the merged image shows the proliferating cells. DHEA, dehydroepiandrosterone; EdU, 5-ethynyl-2'-deoxyuridine.

predominantly exists as a monomer and emits green fluorescence; while at high $\Delta \Psi \mathrm{m}$ conditions, JC-1 forms aggregates and emits a red fluorescence. The average fluorescence intensity was calculated in 10 randomly selected fields using Image Pro Plus software, version 6.0 (Media Cybernetics, Inc., Rockville, MD, USA), and the 590/530 nm fluorescence intensity ratio was used as an index for $\Delta \Psi \mathrm{m}$.
Analysis of succinate dehydrogenase activity. Primary rat Leydig cells were cultured in 6-well plates $\left(1 \times 10^{6}\right.$ cells/well $)$ and treated with 1,50 and $100 \mu \mathrm{M}$ DHEA for $24 \mathrm{~h}$. Following incubation, cells were harvested and sonicated, then centrifuged at $2500 \mathrm{x} \mathrm{g}$ for $10 \mathrm{~min}$ at $4^{\circ} \mathrm{C}$. Supernatants were collected and succinate dehydrogenase activity determined by a continuous spectrophotometric method, according to 
A

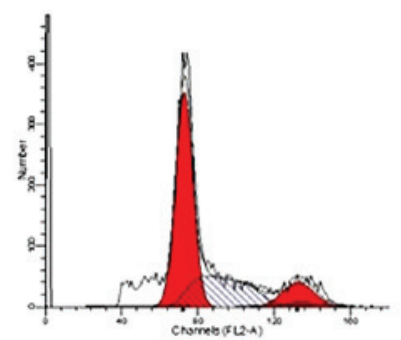

B

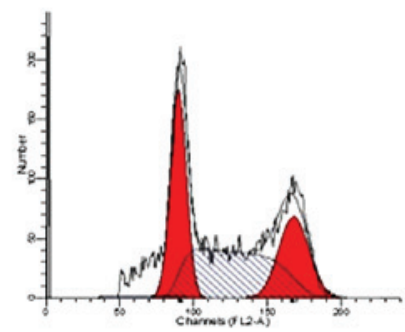

C

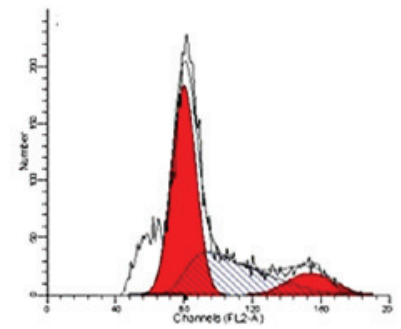

$\mathbf{D}$

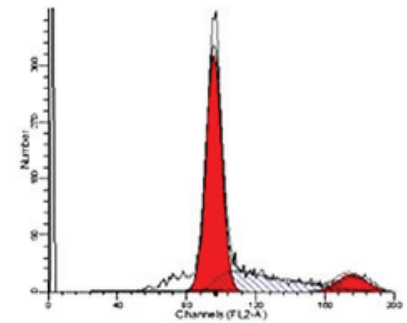

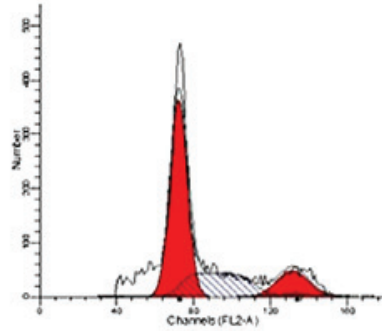
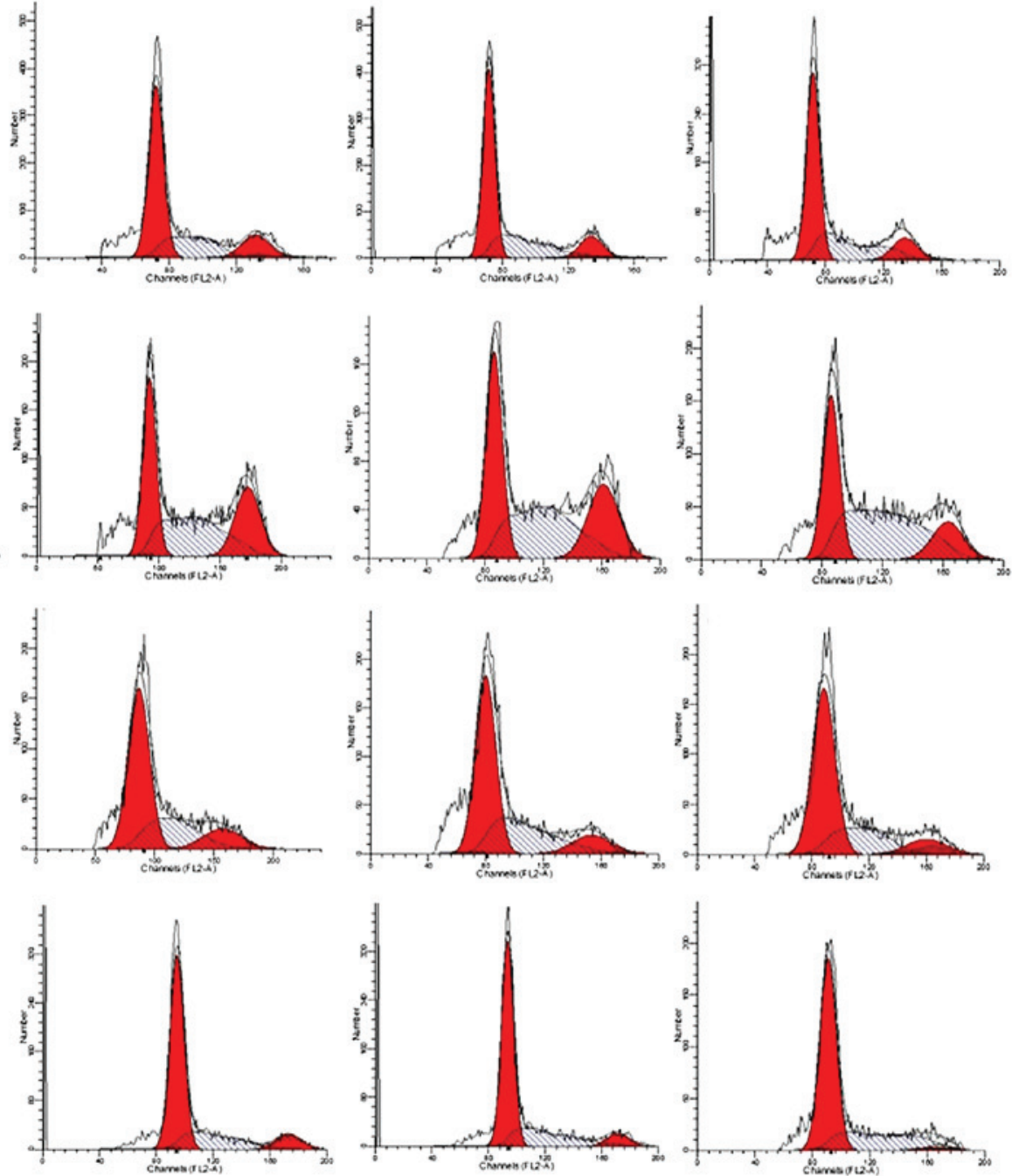

Figure 3. Effect of DHEA on cell cycle in primary rat Leydig cells. The effect of DHEA on primary Leydig cell cycle was evaluated using flow cytometric analysis. The cells were analyzed following treatment with 0, 1, 50 and $100 \mu \mathrm{M}$ DHEA (left to right) at (A) $6 \mathrm{~h},(\mathrm{~B}) 12 \mathrm{~h},(\mathrm{C}) 24 \mathrm{~h}$ and (D) $48 \mathrm{~h}$. Cell cycle distribution was calculated from 10,000 cells with ModFit LTTM software using FACSCaliber. DHEA, dehydroepiandrosterone.

manufacturer's instructions (Jianchen Biotechnology Institution, Nanjing, China). Data were normalized to the sample protein concentration, as determined by a protein assay kit.

Statistical analysis. Data were analyzed with one-way analysis of variance and expressed as the mean \pm standard error. Differences between individual groups were analyzed by Duncan's multiple comparison tests. $\mathrm{P}<0.05$ was considered to indicate a statistically significant difference. All statistical analyses were performed with SPSS software for Windows (version 13; SPSS, Inc., Chicago, IL, USA).

\section{Results}

Effect of DHEA on cell viability in primary Leydig cells. The present study determined the effect of DHEA on primary rat Leydig cell viability using the MTT method. As presented in Table II, cell viability was increased in the 50-200 $\mu \mathrm{M}$ DHEA-treated groups at 6-48 $\mathrm{h}$ compared with the control group $(\mathrm{P}<0.01)$. Additionally, cell viability was increased in presence of 0.1-10 $\mu \mathrm{M}$ DHEA at 24-48 $\mathrm{h}$ compared with the control group $(\mathrm{P}<0.01)$.
Effect of DHEA on cell proliferation in primary Leydig cells. According to cell viability results, DHEA concentrations of 1, 50 and $100 \mu \mathrm{M}$ were used to treat primary rat Leydig cells in all subsequent experiments. The results demonstrated that DHEA significantly inhibited primary rat Leydig cell growth (Fig. 1). To confirm this result, a Click-iT EdU assay was used to examine the effect of DHEA on cell proliferation. As demonstrated in Fig. 2, proliferating primary rat Leydig cells that incorporated the nucleoside are red. Nuclei were counterstained with Hoechst 33342 (blue) and pink color in the merged image demonstrated the proliferating cells only. Our results showed that DHEA treatment markedly inhibited primary rat Leydig cell proliferation compared with controls in a dose-dependent manner.

Effect of DHEA on the cell cycle in primary Leydig cells. The cell cycle was evaluated by flow cytometry (Fig. 3 and Table III). After $48 \mathrm{~h}$ exposure to $50 \mu \mathrm{M}$ DHEA, the cell population in $\mathrm{S}$ phase was significantly increased $(\mathrm{P}<0.01)$, whereas the population in $\mathrm{G} 2 / \mathrm{M}$ was significantly decreased $(\mathrm{P}<0.01)$ compared with the control group. Furthermore, the $\mathrm{S}$ phase population was significantly increased $(\mathrm{P}<0.01)$ and 
G2/M cell population decreased $(\mathrm{P}<0.01)$ compared with the control group following $100 \mu \mathrm{M}$ DHEA incubation for $12-48 \mathrm{~h}$ in primary Leydig cells. No differences in the cell cycle were detected in $1 \mu \mathrm{M}$ DHEA-treated primary Leydig cells compared with the control group $(\mathrm{P}>0.05)$.

Effect of DHEA on cyclin mRNA levels in primary Leydig cells. The level of cyclin mRNA was significantly decreases in the $100 \mu \mathrm{M}$ DHEA-treated group compared with the control group $(\mathrm{P}<0.01$; Fig. 4A). No significant change was observed in the cyclin B mRNA level (Fig. 4B), whereas the CDK2 mRNA level was significantly decreased in the $1 \mu \mathrm{M}(\mathrm{P}<0.05)$ and $100 \mu \mathrm{M}(\mathrm{P}<0.01)$ DHEA-treated groups compared with the control group (Fig. 4C).

Morphological observations and quantization of mitochondria. The histological organization of cultured primary Leydig cells was not altered by DHEA treatment (Fig. 5). The number of mitochondria in 15 independent cells from 30 randomly selected fields were counted with no significant change observed in the DHEA treated groups compared with the control group $(\mathrm{P}<0.05$; Fig. 5).

Effect of DHEA on the permeability of the mitochondrial membrane in primary Leydig cells. $\Delta \Psi \mathrm{m}$ was significantly decreased in $100 \mu \mathrm{M}$ DHEA-treated cells compared with control cells $(\mathrm{P}<0.01)$, whereas only a marginal decrease was observed in 1 or $50 \mu \mathrm{M}$ DHEA-treated cells compared with control cells ( $\mathrm{P}>0.05$; Fig. 6). This result indicated that $100 \mu \mathrm{M}$ DHEA treatment decreased the mitochondrial membrane permeability in primary Leydig cells.

Effect of DHEA on succinate dehydrogenase activity in primary Leydig cells. No significant difference in succinate dehydrogenase activity was observed in the $1 \mu \mathrm{M}$ DHEA-treated group compared with the control group ( $\mathrm{P}>0.05)$, whereas succinate dehydrogenase activity was significantly increased in the 50 and $100 \mu \mathrm{M}$ DHEA-treated groups compared with the control group $(\mathrm{P}<0.01$; Fig. 7$)$.

\section{Discussion}

The major outcome of this study demonstrated that DHEA inhibits cell proliferation through reducing cyclin mRNA expression levels, whereas it markedly improves cell viability by increasing the mitochondrial membrane permeability and succinate dehydrogenase activity in primary Leydig cells. The majority of endogenous DHEA is secreted by the adrenal cortex with some produced by the testes and ovaries (1). DHEA possesses anti-proliferate activity in various cell types (10-12). However, little is known about its effect on primary rats Leydig cell proliferation. In the present study, microscopy demonstrated that DHEA treatment significantly inhibits primary Leydig cell growth. Suzuki et al (22) previously reported that DHEA modulates neuronal stem cell proliferation, and Sicard et al (23) demonstrated that DHEA modulates growth factor-induced proliferation in bovine adrenomedullary tissue. The EdU assay is based on a copper-catalyzed covalent reaction between a dye-conjugated azide and the alkyne group of EdU (24-27), the product readily incorporates into the DNA of 


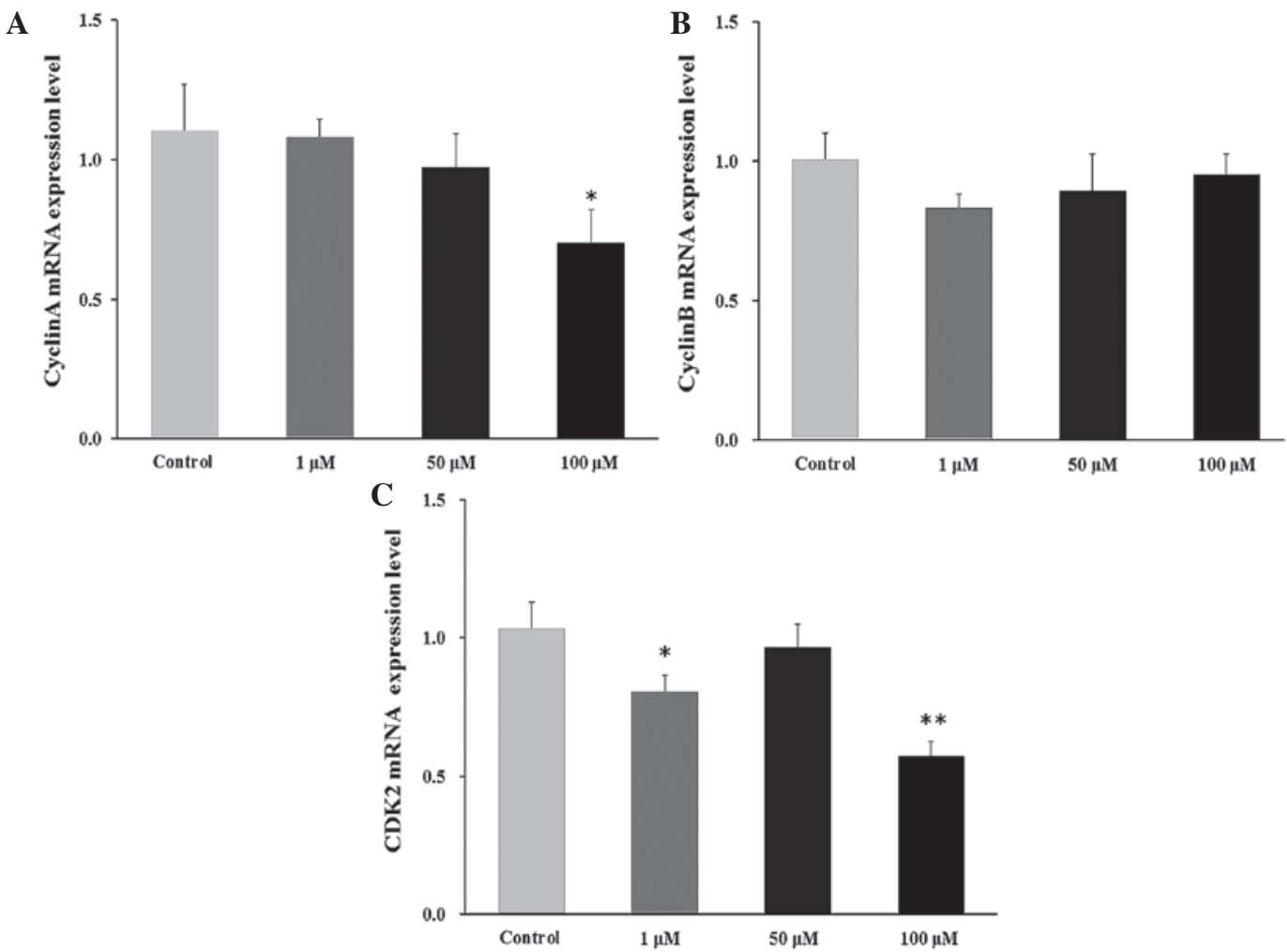

Figure 4. Effect of DHEA on cyclin mRNA expression level in primary rat Leydig cells. (A) Cyclin A (B) cyclin B and (C) CDK2 mRNA expression levels were measured following DHEA treatment. Data are presented as the mean \pm standard error from three individual experiments. ${ }^{*} \mathrm{P}<0.05,{ }^{* *} \mathrm{P}<0.01 \mathrm{vs}$. control group. DHEA, dehydroepiandrosterone; CDK2, cyclin-dependent kinase 2.

A

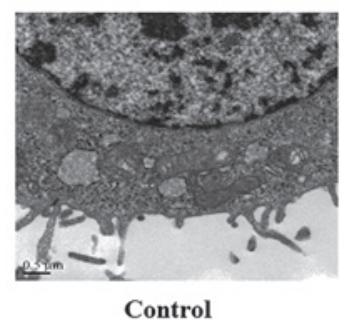

Control

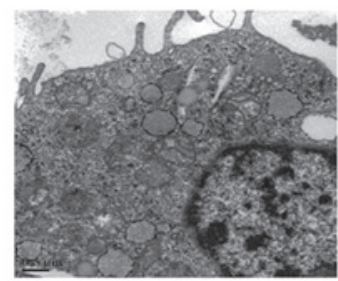

$50 \mu \mathrm{M}$ DHEA

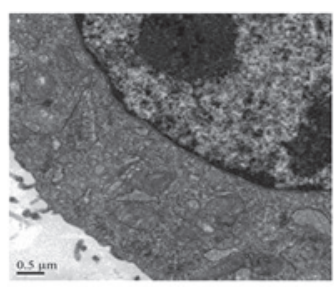

$1 \mu \mathrm{M}$ DHEA

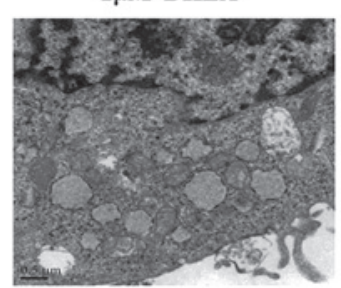

$100 \mu \mathrm{M}$ DHEA
B

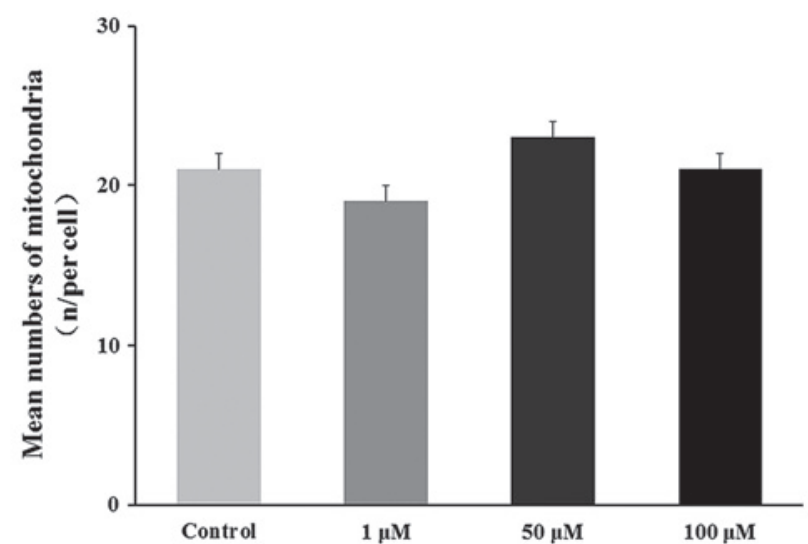

Figure 5. Electron micrographs and the number of mitochondria. (A) Following DHEA treatment, cell samples were processed by standard techniques for transmission electron microscopy, and ultra-thin sections were observed at x2,500 magnification. (B) The number of mitochondria was counted in 15 independent cells in 30 randomly selected micrographs. The results are presented as number of mitochondria per cell in all treatment groups (the mean \pm standard error). DHEA, dehydroepiandrosterone.

replicating cells, including $\mathrm{NIH} 3 \mathrm{~T} 3$ cells $(26,28)$ and mouse T-cells (29). The results of the current study demonstrated that DHEA significantly decreases primary Leydig cell proliferation in a dose-dependent manner, and this result is consistent with the observations made using phase contrast microscopy. It has been previously reported that DHEA inhibits the proliferation of several types of cancer cells, including hepatoma, prostate and cervical cancer (30-33). A previous study also observed that DHEA induces proliferation of estrogen and androgen receptor-positive breast cancer cells, whereas it inhibits the proliferation of estrogen receptor-negative cells (34). It is well recognized that Leydig cells express estrogen and androgen receptors (35). However, López-Marure et al (33) reported that DHEA decreases both estrogen receptor-positive and -negative breast cancer cell proliferation. Thus, based on the results of the current study, it is speculated that the presence of estrogen 

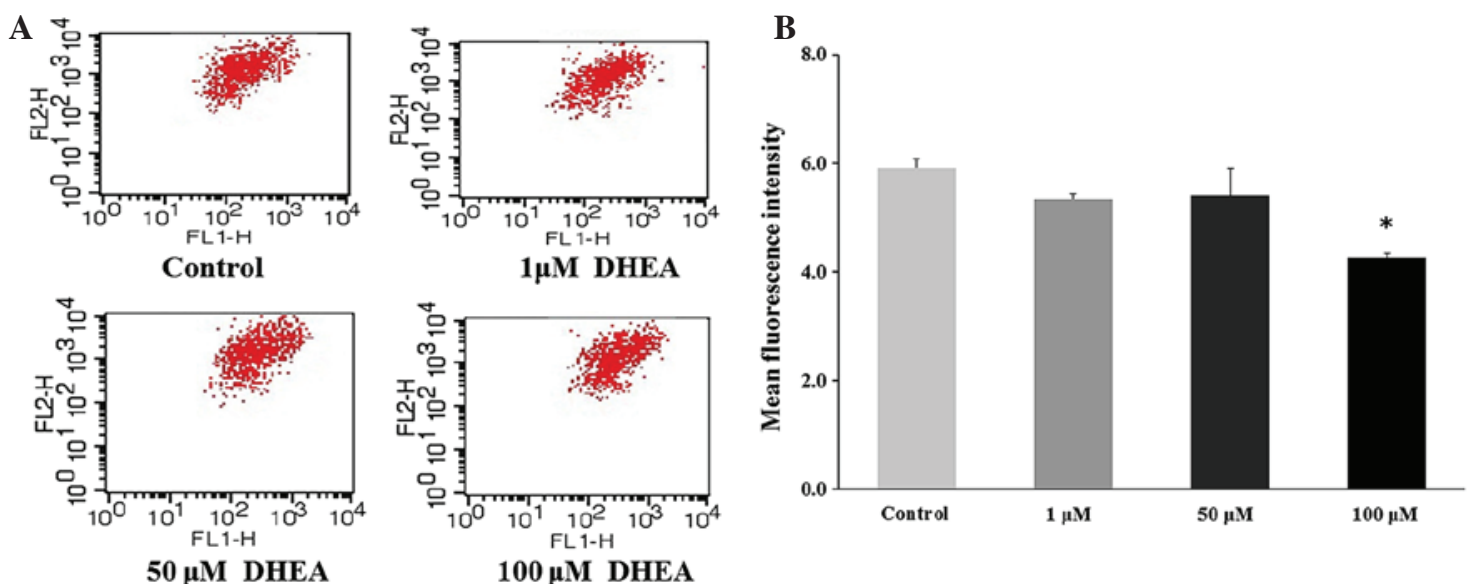

Figure 6. Effect of DHEA on mitochondrial permeability. (A) Typical mitochondrial permeability images from Leydig cells treated with DHEA. (B) The $\Delta \Psi \mathrm{m}$ as indicated by the $590 / 530 \mathrm{~nm}$ fluorescence intensity ratio. Data are presented as the mean \pm standard error from three individual experiments. " $\mathrm{P}<0.05$, vs. control group. DHEA, dehydroepiandrosterone.

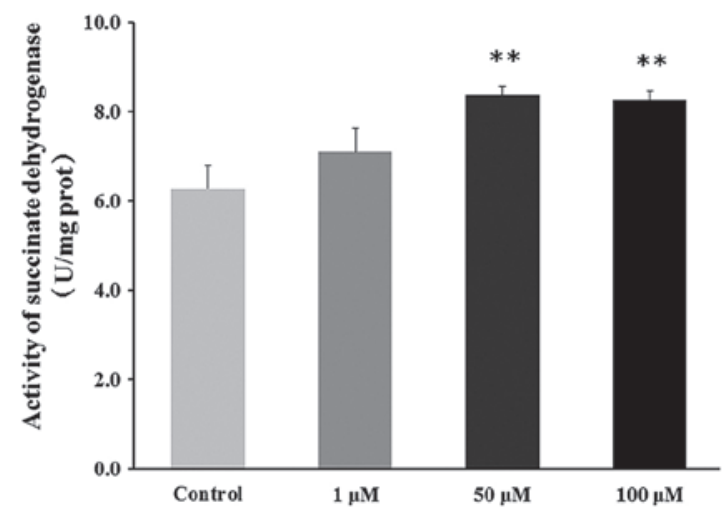

Figure 7. Effect of DHEA on succinate dehydrogenase activity. Data are presented as the mean \pm standard error from three individual experiments. ${ }^{* *} \mathrm{P}<0.01$ vs. control group. DHEA, dehydroepiandrosterone.

or androgen receptors may not be essential for the cell proliferation induced by DHEA, and further study is required to precisely validate the effect of DHEA on cell proliferation.

Certain evidence suggests that the inhibitory effect of DHEA on cell proliferation is associated with the changes in the phases of the cell cycle $(31,33)$. The present study demonstrated that 50 or $100 \mu \mathrm{M}$ DHEA treatment increased the $\mathrm{S}$ phase cell population and decreased the G2/M population, indicating that DHEA inhibits primary rat Leydig cell proliferation and causes cell cycle arrest in S phase. These results are consistent with a previous study that suggested that DHEA inhibits cell proliferation and blocks cell cycle progression at the G1/S stage in 3T3-L1 cells (14). To investigate the effect of DHEA on the cell cycle, the levels of cyclin mRNA were assessed. The results demonstrated that cyclin A and CDK2 mRNA levels were significantly decreased following $100 \mu \mathrm{M}$ DHEA treatment, whereas no significant change in cyclin B mRNA level was observed in primary Leydig cells. In eukaryotes, the cell cycle is regulated by cyclins, CDKs and CDK inhibitors. Particularly, cyclin $\mathrm{A} / \mathrm{CDK} 2$ are involved in regulating the progression of $\mathrm{S}$ phase and cyclin $\mathrm{B} / \mathrm{CDK} 1$ are involved in regulating the progression of $\mathrm{G} 2 / \mathrm{M}$ phase (36). A previous study demonstrated that the inhibitory effect of DHEA on the proliferation of MCF-7 cells was associated with an arrest in G1 phase (33). Also, it has been previously reported that the effect of DHEA on the MCF-7 cell cycle is potentially dependent on DHEA metabolism to androstenediol (37). Based on the results of the current study, it is speculated that the inhibition of proliferation induced by DHEA is associated with the decrease in cyclin A and CDK2 mRNA levels, which in turn would then induce cell cycle arrest in S phase, and this action of DHEA may occur with conversion in primary Leydig cells. Further investigation of the mRNA or protein levels of other factors, including CDK1 and cyclin E, which are also associated with the cell cycle, is required to validate this hypothesis more precisely.

It is notable that DHEA inhibited primary rat Leydig cell proliferation, whereas it increased cell viability in a time- and dose-dependent manner. In contrast with the results of the present study, previous reports have demonstrated that DHEA inhibits BV-2 cell viability $(12,38)$, however this effect was observed using ethanol as the solvent. It has been previously reported that ethanol treatment results in a slight decrease in cell viability. In the previous study, cell viability was decreased by $8 \%$ at $1 \%$ ethanol, which was highest final concentration used (13). The present study demonstrated that the cell viability gradually improved throughout the experimental period in the control group (0.1\% DMSO), which indicated that normal cell growth was maintained. Thus, the use of different solvent may be the reason for the discrepancy in the effect of DHEA on cell viability. To further investigate the effect of DHEA on cell viability, the mitochondria number, $\Delta \Psi \mathrm{m}$ and succinate dehydrogenase activity were subsequently analyzed. No significant change was detected in mitochondria number and their configuration in primary Leydig cells following DHEA treatment. However, previous studies have demonstrated that DHEA affects mitochondrial number and configuration in chicken hepatocytes (20) and the liver of male rats (39). DHEA also increases fatty acid $\beta$-oxidation and enhances mitochondrial respiration, which may be the cause of the decrease in mitochondria number in the rat or chicken liver cells $(20,39)$. The probable explanation for these inconsistent results may be attributed to the different cell types used in the studies. 
Cell viability analysis was performed based on the quantity of formazan produced from MTT by mitochondrial enzymes (40). The double membrane structure of the mitochondria blocks the entry of MTT into the mitochondria. The result of the current study demonstrated that DHEA treatment decreases the transmembrane $\Delta \Psi \mathrm{m}$ of primary Leydig cells, and the lowest $\Delta \Psi \mathrm{m}$ was evident in the $100 \mu \mathrm{M}$ DHEA-treated group. This result indicated that the permeability of the mitochondrial membrane was significantly increased in primary Leydig cells treated with DHEA. Furthermore, this is consistent with a previous study, in which the $\Delta \Psi \mathrm{m}$ declined following treatment of isolated kidney cortex mitochondria with high concentrations of DHEA (15). Shen et al (19) reported that mitochondrial membrane permeability was significantly increased in TM-3 cells following DHEA treatment. It has previously been reported that DHEA administration to rats induces lipid peroxidation in the liver and heart mitochondria (41). In this respect, it has previously been demonstrated that mitochondrial membrane lipid peroxidation causes an increase in permeability (42). These previous studies, at least partially, indicate that increased primary Leydig cells viability induced by DHEA is associated with the increased mitochondrial membrane permeability. Succinate dehydrogenase is the only membrane bound enzyme in the Krebs cycle, which directly links the oxidation of succinate to the electron transport chain. The current study demonstrated that succinate dehydrogenase activity was significantly increased in primary Leydig cells following 50 or $100 \mu \mathrm{M}$ DHEA treatment. DHEA has previously been demonstrated to inhibit nicotinamide adenine dinucleotide-dependent mitochondrial respiration and Complex I of the mitochondrial respiratory chain (43), which results in ATP depletion and the compensatory provision of ATP through glucose oxidization (12). Sato et al (44) reported that GLUT-4 protein expression level was increased and the glucose metabolic signaling pathway was activated in skeletal muscle cells following DHEA-treatment. Jahn et al (45) demonstrated that muscle glucose oxidation was increased by $120 \%$ in diabetic Wistar rats treated with DHEA. Thus, the effect of DHEA on succinate dehydrogenase activity may be associated with its energy-wasting properties.

In summary, the results of the present study, at least partially, demonstrate that DHEA-induced inhibition of primary rat Leydig cell proliferation involves decreased cyclin mRNA expression levels, which results in cell cycle arrest in $\mathrm{S}$ phases. However, DHEA treatment improves cells viability by modulating mitochondrial membrane permeability and succinate dehydrogenase activity. However, further investigation is required to fully elucidate the effect of DHEA on cell proliferation and viability in primary rat Leydig cells.

\section{Acknowledgements}

The current work was supported by the Priority Academic Program Development of Jiangsu Higher Education Institutions.

\section{References}

1. Savineau JP, Mathan R and Dumas de la Roque E: Role of DHEA in cardiovascular diseases. Biochem Pharmacol 85: 718-726, 2013.

2. Sato K, Iemitsu M, Aizawa K, Mesaki N, Ajisaka R and Fujita S: DHEA administration and exercise training improves insulin resistance in obese rats. Nutr Metab (Lond) 9: 47, 2012.
3. Arnold JT, Gray NE, Jacobowitz K, Viswanathan L, Cheung PW, McFann KK, Le H and Blackman MR: Human prostate stromal cells stimulate increased PSA production in DHEA-treated prostate cancer epithelial cells. J Steroid Biochem Mol Biol 111: 240-246, 2008

4. Kurita H, Maeshima H, Kida S, Matsuzaka H, Shimano T, Nakano Y, Baba H, Suzuki T and Arai H: Serum dehydroepiandrosterone (DHEA) and DHEA-sulfate (S) levels in medicated patients with major depressive disorder compared with controls. J Affect Disord 146: 205-212, 2013.

5. Legrain S and Girard L. Pharmacology and therapeutic effects of dehydroepiandrosterone in older subjects. Drugs Aging 20: 949-967, 2003

6. Schwartz AG and Pashko LL: Dehydroepiandrosterone, glucose-6-phosphate dehydrogenase and longevity. Ageing Res Rev 3: 171-187, 2004.

7. Labrie F, Bélanger A, Bélanger P, Bérubé R, Martel C, Cusan L, Gomez J, Candas B, Chaussade V, Castiel I, et al: Metabolism of DHEA in postmenopausal women following percutaneous administration. J Steroid Biochem Mol Biol 103: 178-188, 2007.

8. Song L, Tang X, Kong Y, Ma H and Zou S: The expression of serum steroid sex hormones and steroidogenic enzymes following intraperitoneal administration of dehydroepiandrosterone (DHEA) in male rats. Steroids 75: 213-218, 2010.

9. Baulieu EE, Thomas G, Legrain S, Lahlou N, Roger M, Debuire B, Faucounau V, Girard L, Hervy MP, Latour F, et al: Dehydroepiandrosterone (DHEA), DHEA sulfate and aging: Contribution of the DHEAge Study to a sociobiomedical issue. Proc Natl Acad Sci USA 97: 4279-4284, 2000.

10. Dashtaki R, Whorton AR, Murphy TM, Chitano P, Reed W and Kennedy TP: Dehydroepiandrosterone and analogs inhibit DNA binding of AP-1 and airway smooth muscle proliferation. J Pharmacol Exp Ther 285: 876-883, 1998.

11. Di Monaco M, Pizzini A, Gatto V, Leonardi L, Gallo M, Brignardello E and Boccuzzi G: Role of glucose-6-phosphate dehydrogenase inhibition in the antiproliferative effects of dehydroepiandrosterone on human breast cancer cells. Brit J Cancer 75: 589-592, 1997.

12. Yang NC, Jeng KC, Ho WM and Hu ML: ATP depletion is an important factor in DHEA-induced growth inhibition and apoptosis in BV-2 cells. Life Sci 70: 1979-1988, 2002.

13. Rice SP, Zhang L, Grennan-Jones F, Agarwal N, Lewis MD, Rees DA and Ludgate M: Dehydroepiandrosterone (DHEA) treatment in vitro inhibits adipogenesis in human omental but not subcutaneous adipose tissue. Mol Cell Endocrinol 320: 51-57, 2010

14. Zapata E, Ventura JL, De la Cruz K, Rodriguez E, Damián P, Massó F, Montaño LF and López-Marure R: Dehydroepiandrosterone inhibits the proliferation of human umbilical vein endothelial cells by enhancing the expression of p53 and p21, restricting the phosphorylation of retinoblastoma protein, and is androgen-and estrogen-receptor independent. FEBS J 272: 1343-1353, 2005.

15. Correa F, García N, García G and Chávez E: Dehydroepiandrosterone as an inducer of mitochondrial permeability transition. J Steroid Biochem Mol Biol 87: 279-284, 2003.

16. Murugesan P, Muthusamy T, Balasubramanian K and Arunakaran J: Polychlorinated biphenyl (Aroclor 1254) inhibits testosterone biosynthesis and antioxidant enzymes in cultured rat Leydig cells. Reprod Toxicol 25: 447-454, 2008.

17. Aldred LF and Cooke BA: The effect of cell damage on the density and steroidogenic capacity of rat testis Leydig cells, using an NADH exclusion test for determination of viability. J Steroid Biochem 18: 411-414, 1983.

18. Livak KJ and Schmittgen TD: Analysis of relative gene expression data using real-time quantitative PCR and the 2(-Delta Delta C(T)) method. Methods 25: 402-408, 2001.

19. Shen X, Liu L, Yin F, Ma H and Zou S: Effect of dehydroepiandrosterone on cell growth and mitochondrial function in TM-3 cells. Gen Comp Endocrinol 177: 177-186, 2012.

20. Tang X, Ma H, Huang G, Miao J and Zou S: The effect of dehydroepiandrosterone on lipogenic gene mRNA expression in cultured primary chicken hepatocytes. Eur J Lipid Sci Tech 111: 432-441, 2009.

21. Dickson G R. Practical Methods in Electron Microscopy. Volume 3, part 1. Fixation, Dehydration and Embedding of Biological Specimens. J Anat 124 (Part 2), 1977.

22. Suzuki M, Wright LS, Marwah P, Lardy HA and Svendsen CN: Mitotic and neurogenic effects of dehydroepiandrosterone (DHEA) on human neural stem cell cultures derived from the fetal cortex. Proc Natl Acad Sci USA 101: 3202-3207, 2004. 
23. Sicard F, Ehrhart-Bornstein M, Corbeil D, Sperber S, Krug AW, Ziegler CG, Rettori V, McCann SM and Bornstein SR: Age-dependent regulation of chromaffin cell proliferation by growth factors, dehydroepiandrosterone (DHEA), and DHEA sulfate. Proc Natl Acad Sci USA 104: 2007-2012, 2007.

24. Diermeier-Daucher S, Clarke ST, HillD, Vollmann-Zwerenz A, Bradford JA and Brockhoff G: Cell type specific applicability of 5-ethynyl-2'-deoxyuridine (EdU) for dynamic proliferation assessment in flow cytometry. Cytometry A 75: 535-546, 2009.

25. Kotogány E, Dudits D, Horváth GV and Ayaydin F: A rapid and robust assay for detection of S-phase cell cycle progression in plant cells and tissues by using ethynyl deoxyuridine. Plant Methods 6: 5, 2010.

26. Salic A and Mitchison TJ: A chemical method for fast and sensitive detection of DNA synthesis in vivo. Proc Natl Acad Sci USA 105: 2415-2420, 2008.

27. Warren M, Puskarczyk K and Chapman SC: Chick embryo proliferation studies using EdU labeling. Dev Dyn 238: 944-949, 2009.

28. Chehrehasa F, Meedeniya AC, Dwyer P, Abrahamsen G and Mackay-Sim A: EdU, a new thymidine analogue for labelling proliferating cells in the nervous system. J Neurosci Methods 177: 122-130, 2009

29. Yu Y, Arora A, Min W, Roifman CM and Grunebaum E: EdU incorporation is an alternative non-radioactive assay to $(3) \mathrm{H}$ thymidine uptake for in vitro measurement of mice T-cell proliferations. J Immunol Methods 350: 29-35, 2009.

30. Arnold JT, Liu X, Allen JD, Le H, McFann KK and Blackman MR: Androgen receptor or estrogen receptor-beta blockade alters DHEA-, DHT- and $\mathrm{E}_{2}$-induced proliferation and PSA production in human prostate cancer cells. Prostate 67 $1152-1162,2007$.

31. Girón RA, Montaño LF, Escobar ML and López-Marure R: Dehydroepiandrosterone inhibits the proliferation and induces the death of HPV-positive and HPV-negative cervical cancer cells through an androgen-and estrogen-receptor independent mechanism. FEBS J 276: 5598-5609, 2009.

32. Ho HY, Cheng ML, Chiu HY, Weng SF and Chiu DT: Dehydroepiandrosterone induces growth arrest of hepatoma cells via alteration of mitochondrial gene expression and function. Int J Oncol 33: 969-977, 2008.

33. López-Marure R, Contreras PG and Dillon JS: Effects of dehydroepiandrosterone on proliferation, migration, and death of breast cancer cells. Eur J Pharmacol 660: 268-274, 2011.
34. Toth-Fejel S, Cheek J, Calhoun K, Muller P and Pommier RF: Estrogen and androgen receptors as comediators of breast cancer cell proliferation: Providing a new therapeutic tool. Arch Surg 139: 50-54, 2004.

35. Kumar V, Balomajumder C and Roy P: Disruption of LH-induced testosterone biosynthesis in testicular Leydig cells by triclosan: Probable mechanism of action. Toxicology 250: 124-131, 2008.

36. Han YH, Kim SZ, Kim SH and Park WH: Arsenic trioxide inhibits the growth of Calu- 6 cells via inducing a G2 arrest of the cell cycle and apoptosis accompanied with the depletion of GSH. Cancer Lett 270: 40-55, 2008.

37. Gebäck T, Schulz MMP, Koumoutsakos P and Detmar M: TScratch: A novel and simple software tool for automated analysis of monolayer wound healing assays. Biotechniques 46: 265-274, 2009.

38. Yang NC, Jeng KC, Ho WM, Chou SJ and Hu ML: DHEA inhibits cell growth and induces apoptosis in BV-2 cells and the effects are inversely associated with glucose concentration in the medium. J Steroid Biochem Mol Biol 75: 159-166, 2000

39. Bellei M, Battelli D, Fornieri C, Mori G, Muscatello U, Lardy H and Bobyleva V: Changes in liver structure and function after short-term and long-term treatment of rats with dehydroepiandrosterone. J Nutr 122: 967-976, 1992.

40. Bernas T and Dobrucki J: Mitochondrial and nonmitochondrial reduction of MTT: Interaction of MTT with TMRE, JC-1 and NAO mitochondrial fluorescent probes. Cytometry 47: 236-242, 2002.

41. Swierczynski J and Mayer D: Dehydroepiandrosterone-induced lipid peroxidation in rat liver mitochondria. J Steroid Biochem Mol Biol 58: 599-603, 1996.

42. Maciel EN, Vercesi AE and Castilho RF: Oxidative stress in $\mathrm{Ca}$ (2+)-induced membrane permeability transition in brain mitochondria. J Neurochem 79: 1237-1245, 2001.

43. Safiulina D, Peet N, Seppet E, Zharkovsky A and Kaasik A: Dehydroepiandrosterone inhibits complex I of the mitochondrial respiratory chain and is neurotoxic in vitro and in vivo at high concentrations. Toxicol Sci 93: 348-356, 2006.

44. Sato K, Iemitsu M, Aizawa K and Ajisaka R: Testosterone and DHEA activate the glucose metabolism-related signaling pathway in skeletal muscle. Am J Physiol Endocrinol Metab 294: E961-E968, 2008.

45. Jahn MP, Jacob MH, Gomes LF, Duarte R, Araújo AS, Belló-Klein A, Ribeiro MF and Kucharski LC: The effect of long-term DHEA treatment on glucose metabolism, hydrogen peroxide and thioredoxin levels in the skeletal muscle of diabetic rats. J Steroid Biochem Mol Biol 120: 38-44, 2010 